\title{
Increase in Fish Production Through Bottom-Up Trophic Linkage in Coastal Waters Induced by Nutrients Supplied via Submarine Groundwater
}

\author{
Koji Fujita ${ }^{1}$, Jun Shoji ${ }^{1,2 *}$, Ryo Sugimoto ${ }^{3}$, Toshimi Nakajima ${ }^{3}$, Hisami Honda ${ }^{4}$, \\ Masaru Takeuchi ${ }^{3}$, Osamu Tominaga ${ }^{3}$ and Makoto Taniguchi ${ }^{4}$ \\ ${ }^{1}$ Graduate School of Biosphere Science, Hiroshima University, Higashi-Hiroshima, Japan, ${ }^{2}$ Atmosphere and Ocean \\ Research Institute, The University of Tokyo, Kashiwa, Japan, ${ }^{3}$ Department of Marine Bioscience, Fukui Prefectural University, \\ Obama, Japan, ${ }^{4}$ Research Institute for Humanity and Nature, Kyoto, Japan
}

\section{OPEN ACCESS}

Edited by:

Efthalia Chatzisymeon,

University of Edinburgh,

United Kingdom

Reviewed by:

Wui Seng Ang,

Public Utilities Board, Singapore Alanna L. Lecher,

Lynn University, United States

*Correspondence:

Jun Shoji

jshoji@aori.u-tokyo.ac.jp

Specialty section:

This article was submitted to Water and Wastewater Management, a section of the journal

Frontiers in Environmental Science

Received: 01 March 2019 Accepted: 21 May 2019

Published: 18 June 2019

Citation:

Fujita $K$, Shoji J, Sugimoto $R$, Nakajima T, Honda H, Takeuchi $M$, Tominaga O and Taniguchi M (2019) Increase in Fish Production Through Bottom-Up Trophic Linkage in Coastal Waters Induced by Nutrients Supplied

via Submarine Groundwater.

Front. Environ. Sci. 7:82. doi: 10.3389/fenvs.2019.00082
Submarine groundwater is richer in nutrients compared to surface (river) water and therefore has been considered to be an essential component of biological production in marine coastal ecosystems. However, there has been no information on the effects of submarine groundwater on animals at high-order trophic levels such as fishes. Here, we show the first direct evidence that fish feeding and growth are elevated by submarine groundwater discharge (SGD) by on-site experiments and quantitative sampling. An experiment using cages moored on the sea bottom confirmed that juvenile marbled sole Pseudopleuronectes yokohamae obtained elevated levels of nutrition in the vicinity of SGD. Quantitative sampling at three sites with different hydrodynamic properties in coastal waters of the western North Pacific showed correspondence of high SGD with high biological production or biomass from producer to secondary consumers. These findings demonstrate that nutrients of terrestrial origin provided via submarine groundwater in coastal areas promote marine fish production.

Keywords: groundwater discharge, cage experiment, feeding, flounder, growth, radon, terrestrial origin, trophic flow

\section{INTRODUCTION}

Water flowing from the land to the marine coastal area is an essential component supporting the high biological production by supplying nutrients of terrestrial origin (Field et al., 1998). Freshwater provided from terrestrial areas to coastal areas can be divided into surface water (river water) and groundwater. More studies have been undertaken on how variability in river waters affects biological production in marine ecosystems compared to groundwater supply influences (Moosdorf and Oehler, 2017). Groundwater discharge was estimated to approximate or exceed $50 \%$ of the freshwater input to bays (Valiela et al., 1990; Slomp and van Cappellen, 2004). In a temperate bay, a high contribution of nutrients (e.g., $65 \%$ of total dissolved inorganic phosphorus (DIP) provided through all freshwater) has been estimated to be supplied via submarine groundwater, which is richer in nutrients, especially phosphorus (Sugimoto et al., 2016). Therefore, submarine groundwater is considered to have high potential for promotion of trophic flow in coastal ecosystems.

High levels of submarine groundwater discharge (or seepage: SGD) have been shown to correspond with elevated primary production in coastal waters worldwide (Rodellas et al., 2015; Sugimoto et al., 2017; Figures 1A,B). Recent studies have indicated elevated abundance of primary 


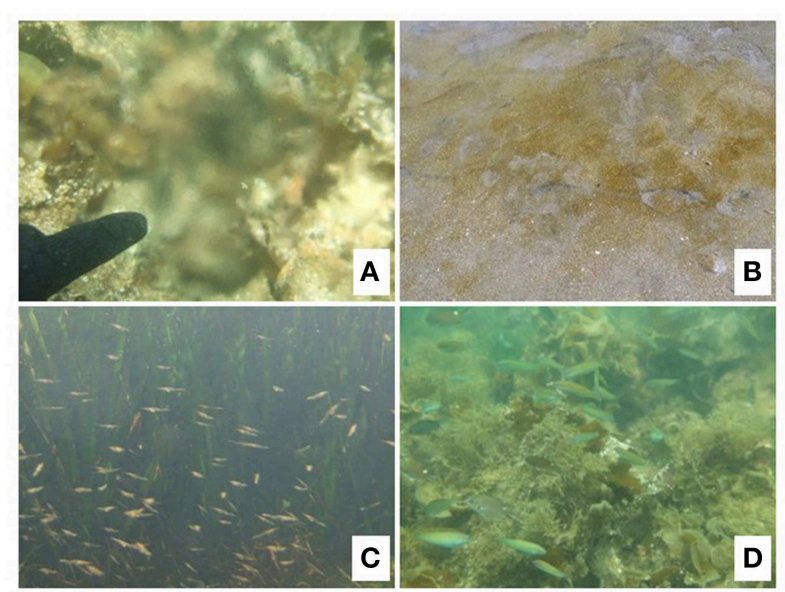

FIGURE 1 | Underwater view of spring-type submarine groundwater discharge (SGD) at a volcanic coast in Beppu Bay, southwestern Japan (A), benthic microalgae flourishing around SGD at a sandy beach in Yamagata Prefecture (B), misids gathering around SGD at a seagrass bed in Hokkaido Prefecture (C), and aggregation of labrid and pomacentrid fishes around SGD in Beppu Bay, Japan (D). All image credits: JS.

and secondary consumers (invertebrate macro-benthos and fishes) in nearby areas containing SGD (Waska and Kim, 2010; Hata et al., 2016; Utsunomiya et al., 2017; Figures 1C,D). Herbivore grazing is influenced by ecological stoichiometry of macrophytes that depend on nitrogen-rich SGD (Tomas et al., 2011; Peterson et al., 2012). To date, however, there is still limited information on the influence of SGD on the production of animal communities at high-order trophic levels, such as secondary consumers including fishes (Sanders et al., 2011; Moosdorf and Oehler, 2017). A missing trophic linkage in the coastal boundary area can be demonstrated if the utilization of nutrients of terrestrial origin provided through SGD by marine animals at the high-order trophic levels is elucidated.

In the present study, to test the hypothesis that nutrients provided via SGD drive marine food web and promote production of animals of high-order trophic levels, productivity and biomass at three trophic levels (producer, primary consumer, and secondary consumer) are compared between areas with high and low SGD in three coastal marine areas with different hydrological features in coastal waters of Japan, the western North Pacific. A continuous mooring time series observation was conducted to evaluate the contribution of SGD to animals at high-order trophic levels by comparing feeding and growth of juvenile fish together with nutrients of terrestrial origin [dissolved inorganic nitrogen (DIN) and DIP], primary productions (phytoplankton and benthic microalgae), and abundance of primary consumers as fish prey.

\section{MATERIALS AND METHODS}

\section{Study Sites}

Three survey sites (Figure 2) were selected to cover the different levels of maximum daily tidal amplitude (DTA) during the spring tide period in the western North Pacific (I: Sea of Japan coast with a low DTA of $0.4 \mathrm{~m}$, II: Pacific coast of Japan with an intermediate DTA of $1.5 \mathrm{~m}$; III: coastal area of the Seto Inland Sea with a high DTA of $4.0 \mathrm{~m}$ ). Field experiments and quantitative sampling were conducted at the three sites to test if production and biomass of organisms at three trophic levels (producer, primary, and secondary consumers) in the benthic ecosystem are elevated in and around the area with high SGD.

Radon-222 $\left({ }^{222} \mathrm{Rn}\right)$ is a naturally occurring radioactive gas and a powerful tracer of groundwater inputs to oceans. The ${ }^{222} \mathrm{Rn}$ concentration is typically two to three orders of magnitude higher in groundwater than in surface waters (Church, 1996; Kim et al., 2005). The ${ }^{222} \mathrm{Rn}$ concentration has been applied as one of the indices for the detection of SGD in shallow waters worldwide since the half-life of ${ }^{222} \mathrm{Rn}$ is $\sim 3.8$ days (Taniguchi et al., 2002; Swarzenski et al., 2007; Charette et al., 2008; Dimova et al., 2009; Santos et al., 2010). Salinity is also an indicator of fresh SGD input because SGD is composed of fresh SGD and recirculated SGD (Stieglitz et al., 2013). In the present study, two sampling stations within each site were selected according to the results of previous ${ }^{222} \mathrm{Rn}$ and salinity measurements (site I: Hosono et al., 2012; Kobayashi et al., 2019; site II: Honda et al., 2015; Shoji et al., 2017; site III: Hata et al., 2016). At each of the three sites, production of benthic microalgae, abundances of gammarid crustaceans (as dominant primary consumer and also as major prey organisms for fish), and carnivorous fishes were compared between the two stations with different levels of ${ }^{222} \mathrm{Rn}$ concentration and salinity in water as an indicator for SGD (sts. a, c, and e for high SGD; sts. b, d, and f for low SGD).

\section{Primary Production and Primary and Secondary Consumers' Biomass}

Surveys for primary production by benthic microalgae and biomass of primary consumers (epibenthic crustaceans) and secondary consumers (carnivorous demersal fishes) were conducted on 5 June at site I, on 2 August at site II, and on 12 June at site III in 2016. Production of benthic microalgae was estimated by an onsite experiment. Four polyethylene plates (30 $\times 25 \mathrm{~cm}, 1.5 \mathrm{~mm}$ thick) were set at $0.3 \mathrm{~m}$ above the sea bottom at each station for 2-5 days. Benthic microalgae on the plate was scraped and filtered onto Whatman GF/C glass-fiber filters. Samples were preserved frozen at $-40^{\circ} \mathrm{C}$ until measurement of dry carbon weight with a mass spectrometer at the Research Institute for Humanity and Nature (RIHN), Kyoto, Japan. Primary production of the benthic microalgae was expressed as increase in carbon weight $\left(\mathrm{mg} \mathrm{C} \mathrm{day}^{-1} \mathrm{~m}^{-2}\right)$. Subsamples were preserved in $10 \%$ seawater formalin and were identified under a binocular microscope to the lowest possible taxon.

Epibenthic invertebrates were collected by towing a sledgenet $(0.4 \mathrm{~m}$ width, $0.3 \mathrm{~m}$ height, and $0.3 \mathrm{~mm}$ mesh) for $20 \mathrm{~m}$ at a velocity of $1.0 \mathrm{~m} \mathrm{~s}^{-1}$. Fish sampling was conducted by a round seine net ( $2 \mathrm{~m}$ high, $30 \mathrm{~m}$ long, and $4 \mathrm{~mm}$ mesh aperture) using the previously described method (Kamimura and Shoji, 2013). Each fish collection covered an area of $100 \mathrm{~m}^{2}$. The invertebrate and fish samplings were conducted at four separate locations randomly selected within each station $(n=4$ for each 


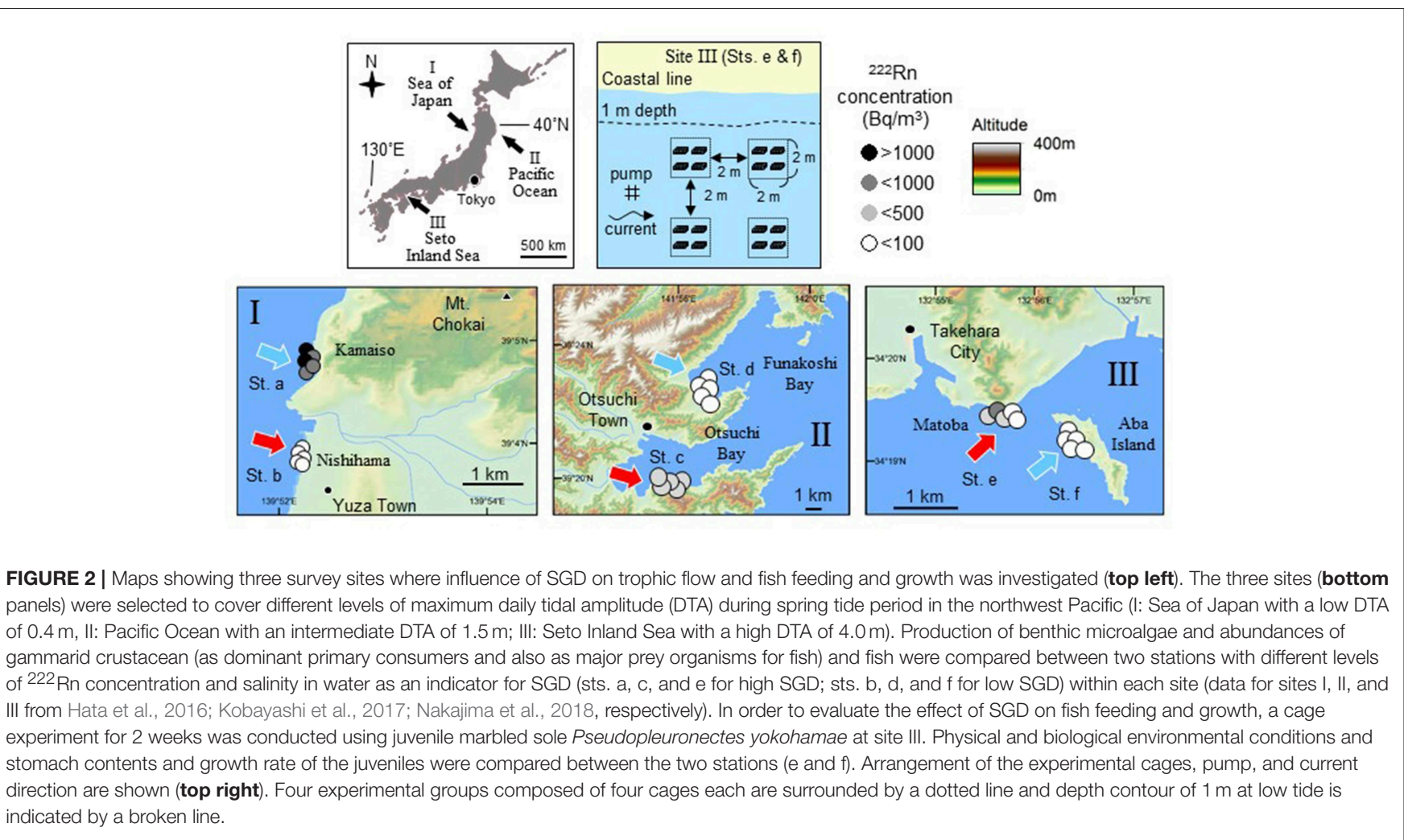

station). Tidal levels ranged from 50 to $130 \mathrm{~cm}$ during these samplings. Samples were preserved on ice and were identified in the laboratory. Abundance of gammarids, which are the major prey items for demersal fishes in the survey sites (Hata et al., 2016; Shoji et al., 2017; Utsunomiya et al., 2017), was expressed as number of individuals $\mathrm{m}^{-2}$. Fish biomass was calculated in wet weight $\left(\mathrm{g} 100 \mathrm{~m}^{-2}\right)$. Subsamples of gammarids and marbled sole were collected at site III and preserved frozen at $-30^{\circ} \mathrm{C}$ until further processing for carbon and nitrogen stable isotope ratios.

\section{Cage Experiment for Fish Feeding and Growth}

To evaluate the effect of SGD on fish feeding and growth, a cage experiment for 2 weeks was conducted using juvenile marbled sole Pseudopleuronectes yokohamae at site III. The marbled sole is widely distributed in coastal waters in the western North Pacific and use low salinity coastal waters as nursery habitats during the juvenile stage (Wada et al., 2007). Juvenile marbled sole are abundant around areas with high SGD on a tidal flat in the Seto Inland Sea, southwestern Japan, and fed mainly on macrobenthos such as polychaetes and gammarids (Hata et al., 2016). Physical and biological environmental conditions and juvenile stomach contents and growth rate were compared between two stations (e and $\mathrm{f}$ ) with different levels of SGD.

St. e is located in an area with high ${ }^{222} \mathrm{Rn}$ concentrations along the coast of Honshu Island, main island of Japan, and the other (st. f) is on the western coast of Aba Island, an unpopulated island. The distance between these two stations is $\sim 1.5 \mathrm{~km}$. There is no river running into adjacent waters at each station. Majority (>A m 85\%) of the sea bottom at both stations is composed of mud and sand with diameter $<2.0 \mathrm{~mm}$ (Hata et al., 2016). Tidal amplitude is $\sim 4 \mathrm{~m}$ during spring tides and $2 \mathrm{~m}$ during neap tides.

Mooring time series surveys were conducted for $24 \mathrm{~h}$ from 16:00 on 6 June to 16:00 on 7 June 2017 at the two stations. Seawater was pumped at $5 \mathrm{~L} \mathrm{~min} \mathrm{mi}^{-1}$ by a submersible bilge pump (800GPH, Rule) from $30 \mathrm{~cm}$ above the seafloor $(1.5 \mathrm{~m}$ of sea depth at low tide). Data loggers for depth (DEFI2-D5HG, JFE Advantech), temperature, and salinity (A7CT2-USB, JFE Advantech) were mounted with the pump. The ${ }^{222} \mathrm{Rn}$ activity in seawater was measured according to Burnett et al. (2001). Seawater was directly flowed into an air/water exchanger (RAD Aqua, Durridge, Inc). Then, equilibrated air was sent into a radon detector (RAD7, Durridge, Inc.) for analysis of ${ }^{222} \mathrm{Rn}$ after passing through desiccant. The ${ }^{222} \mathrm{Rn}$ activity in seawater was measured every $20 \mathrm{~min}$. Atmospheric ${ }^{222} \mathrm{Rn}$ activity was also measured during the same period. Uncertainties based on the counting errors were $<20 \%$ for ${ }^{222} \mathrm{Rn}$. Data obtained by the data loggers and RAD7 were averaged hourly to eliminate shortterm variability in the present study. Hourly changes in SGD and compositions of fresh and recirculated SGDs were analyzed in a previous study (Nakajima et al., 2018).

In order to estimate SGD rate, continuous heat-type automated seepage meters (Taniguchi and Iwakawa, 2001) were deployed near the submersible pump at each site. The sensors were calibrated in the laboratory before and after the field survey. Voltage measured by the seepage meter at 5-min intervals was 
converted into $\mathrm{ml} \mathrm{min}{ }^{-1}$ using calibration curves and then converted to $\mathrm{cm} \mathrm{day}^{-1}$ using the area of the chambers by the same method as Kobayashi et al. (2017). Temperature and salinity were monitored at 5 -min intervals by a temperature and salinity logger (MDS Mk-V, Advantech) attached inside the chamber.

Nutrient samples $\left(\mathrm{NO}_{3}^{-}, \mathrm{NO}_{2}^{-}, \mathrm{NH}_{4}^{+}\right.$, and $\left.\mathrm{PO}_{4}^{3-}\right)$ were collected hourly from the pumped water and were immediately filtered through syringe filters (ADVANTEC, cellulose-acetate membrane, $0.8 \mu \mathrm{m}$ pore size). Concentrations of $\mathrm{NO}_{3}^{-}, \mathrm{NO}_{2}^{-}$, and $\mathrm{PO}_{4}^{3-}$ were measured using an autoanalyzer (TRAACS-800, Bran-Luebbe). $\mathrm{NH}_{4}^{+}$concentration was measured fluorometrically using the orthophthaldialdehyde method (Holmes et al., 1999) with a Trilogy fluorometer with a colored dissolved organic matter $(\mathrm{CDOM}) / \mathrm{NH}_{4}$ module (Model 7200041, Turner Designs). We defined DIN as the sum of $\mathrm{NO}_{3}^{-}$, $\mathrm{NO}_{2}^{-}$, and $\mathrm{NH}_{4}^{+}$, and DIP as $\mathrm{PO}_{4}^{3-}$. Chlorophyll-a (Chl-a) concentration in the pumped water was measured using the calibrated chlorophyll sensor (Cyclops-7, Turner Designs). These measurements were conducted every hour.

Feeding and growth of juvenile marbled sole were compared between the two stations (e and f). Juvenile marbled sole cultured at Kudamatsu Sea-farming Center, Yamaguchi Prefecture, Japan, were transported to the Takehara Marine Laboratory, Hiroshima University, and were maintained in a stocking tank for 4 days. On 12 June 2017, each juvenile (mean body length: $49.7 \mathrm{~mm}$, SD: 2.8$)$ was separately put in a cage $(0.45 \times 0.45 \times 0.3 \mathrm{~m})$. The juvenile stocking density for the experiment $\left(4.9\right.$ ind. $\left.\mathrm{m}^{-2}\right)$ was maintained at less than half of that $\left(9.9\right.$ ind. $\mathrm{m}^{-2}$ ) found to be suitable for juvenile feeding and growth according to the previous experiment to evaluate appropriate juvenile stocking density for the cage experiment (Fujita et al., 2017). Four cages were set within an experimental square of $2 \times 2 \mathrm{~m}$ on the sea bottom at the two stations. Four experimental squares were located within a larger $6 \mathrm{~m} \times 6 \mathrm{~m}$ square at each station. As a result, a total of 16 $(4 \times 4)$ experimental cages composed of four groups (four cages per group) were set at each station.

On 26 June, the juvenile marbled sole were collected from each cage and was preserved on ice. Total length of each juvenile was measured at the start and end of the experiment. Mean absolute growth rate $\left(\mathrm{G}, \mathrm{mm} \mathrm{day}^{-1}\right)$ for the experimental period (14 days) was calculated as:

$$
G=\left(L_{14}-L_{0}\right) / 14
$$

where $L_{14}$ is the total length at the end of the experiment (day 14) and $L_{0}$ is that at the start of the experiment (day 0 ).

Stomach contents of the juvenile marbled sole were identified under a dissecting microscope at a maximum of $100 \times$ magnification. Each prey item was measured in length and width using an ocular micrometer. Prey mass was calculated from previously reported length-mass relationships of Sirois and Dodson (2000). Stomach content composition (\% in weight) was calculated for each juvenile.

Stable carbon isotope ratio analysis was applied for the wild and cultured juvenile marbled sole and their possible prey items in order to obtain verification that nutritional source of the juveniles in the experimental cages shifted from artificial pellets fed in the tank prior to the experiment to wild prey organisms in nature during the field experiment. The half-life period of carbon stable isotopic ratios in marbled sole juvenile muscles has been reported to be about 2 weeks in a diet-switch experiment (Hamaoka et al., 2016). Twenty cultured juveniles (fed only hatchery pellets) were sampled from the stocking tank at the start of the experiment. Fifteen juveniles cultured and kept in the cages for 2 weeks (fed natural prey for 2 weeks) were sampled from sts. e and $\mathrm{f}$, respectively (one fish was lost/dead during the experiment at each station), at the end of the cage experiment.

Muscles of the right side of the body of wild juveniles collected at sts. e $(n=20)$ and $\mathrm{f}(n=6)$, hatchery pellet $(n=4)$, and gammarids collected at sts. e and $\mathrm{f}$ as major prey organisms for the wild juveniles ( $n=4$ for each station, bulk sample) were processed for stable isotope analysis following the methods of Nagata and Miyajima (2008).

Stable isotope ratios of carbon $\left(\delta^{13} \mathrm{C}\right)$ and nitrogen $\left(\delta^{15} \mathrm{~N}\right)$ were measured with an isotope mass spectrometer fitted with an elemental analyzer at RIHN. Isotope ratios are expressed as:

$$
\delta X=\left(R_{\text {sample }} / R_{\text {standard }}-1\right) \times 1000
$$

where $\delta X$ is the stable isotope $\left(\delta^{13} \mathrm{C}\right.$ or $\left.\delta^{15} \mathrm{~N}\right)$ in units of \%o, and $R={ }^{13} \mathrm{C} /{ }^{12} \mathrm{C}$ or ${ }^{15} \mathrm{~N} /{ }^{14} \mathrm{~N}$. Atmospheric nitrogen $\left(\mathrm{N}_{2}\right)$ and Pee Dee belemnite were used as the standards for nitrogen and carbon stable isotopes, respectively. In order to verify the accuracy of the analysis, DL-alanine was used as a secondary standard for carbon. Precision for isotopic analysis was within $\pm 0.28 \%$ for both $\delta^{13} \mathrm{C}$ and $\delta^{15} \mathrm{~N}$.

\section{Statistical Analyses}

Production of benthic microalgae; gammarid and fish abundance at sites I, II, and III (four replicates for each); stomach content weight; and growth rate of juvenile marbled sole by experimental group were compared between the two stations (four replicates for each value per station) by Mann-Whitney $U$-test. Hourly SGD, salinity, DIN, DIP, Chl-a, and stomach content weight and growth rate of individual juvenile were compared between the two stations by Student's $t$-test. Stable carbon isotope ratio of the juveniles used for the cage experiment ( $n=15$ for each) and wild ( $n=20$ at st. e and $n=6$ at st. f) was compared between the two stations by Mann-Whitney $U$-test. All of the statistical analyses were performed in R (3.4.1: R Development Core Team).

\section{RESULTS}

\section{Primary Production and Primary and Secondary Consumers' Biomass at the Three Sites}

At all sites (I, II, and III), the benthic microalgae production was significantly higher at the stations with a higher SGD signal (sts. a, c, and e) than at the stations with a lower SGD signal (sts. b, d, and f: Mann-Whitney $U$-test, $p<0.05$ for all, Figure 3). The benthic microalgae were mostly composed of Amphora spp., Navicula spp., and Synedra spp. at all sites. The dominant fish species were Japanese sillago (Sillago japonica), surfperches (Embiotocidae spp.), and red seabream (Pagrus major) at sitessite I, II, and III, 


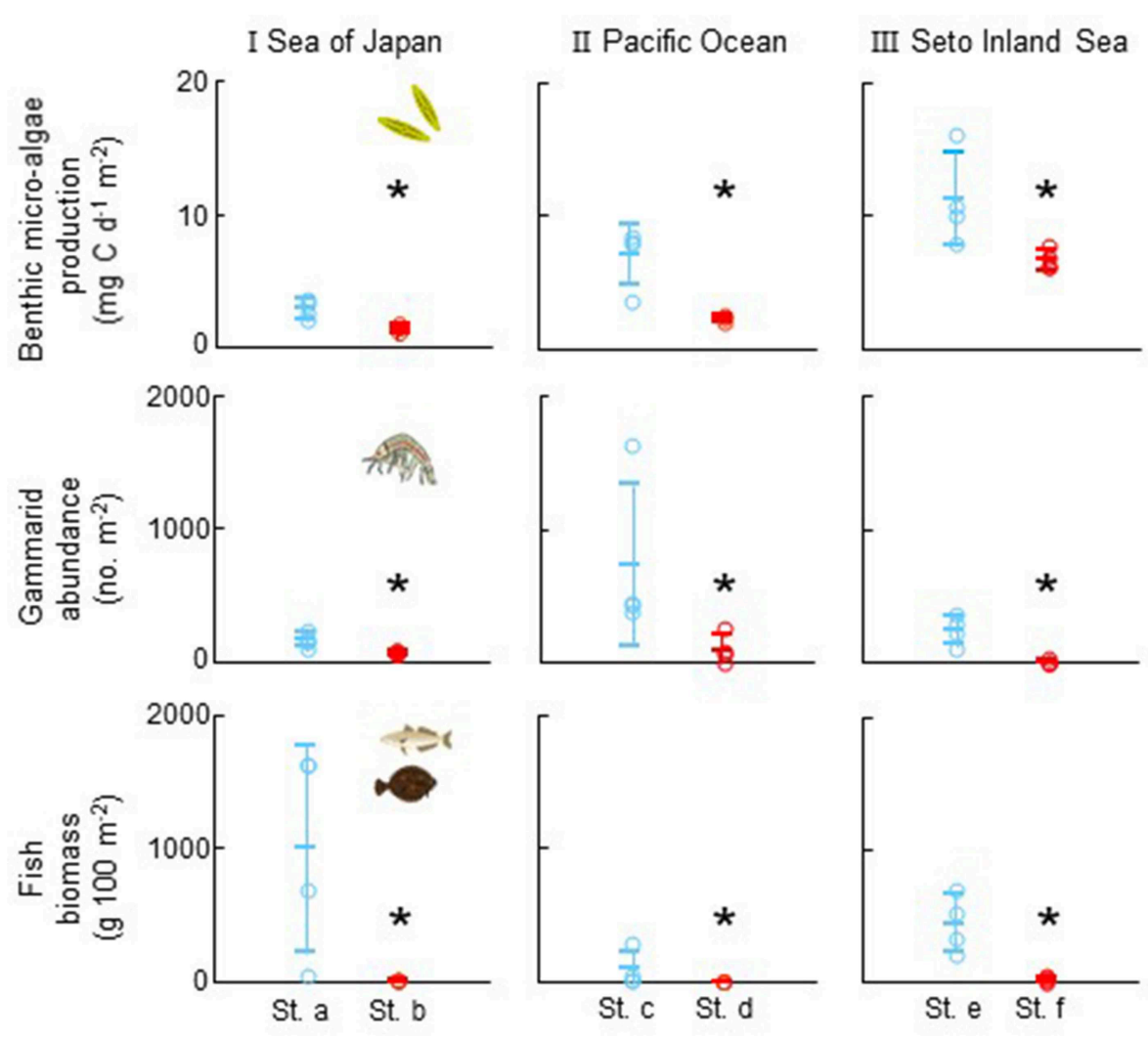

FIGURE 3 | Comparison of benthic microalgae production (top), abundance of gammarids (as dominant primary consumer and also as major prey organisms for fish: middle) and fish biomass (bottom) between the two stations with different levels of ${ }^{222}$ Rn concentrations as an indicator of SGD within each site (I: Sea of Japan, II: Pacific Ocean, and III: Seto Inland Sea). Circles indicate each data and bars show mean and standard deviation. Asterisk shows significant difference within each site (Mann-Whitney U-test, $p<0.05$ for all).

respectively. The abundance of both gammarids and fishes was also significantly higher at the stations with higher SGD signal than at the stations with lower SGD signal (Mann-Whitney $U$-test, $p<0.05$ for all, Figure 3).

\section{Submarine Groundwater Discharge, Nutrient Supply, and Chlorophyll-a Concentration During the Mooring Time Series Surveys}

During the mooring time series survey conducted at site III for the cage experiment, the mean hourly ${ }^{222} \mathrm{Rn}$ concentrations ranged between 31.6 and $97.9 \mathrm{~Bq} \mathrm{~m}^{-3}$ at st. e and between 23.8 and $70.6 \mathrm{~Bq} \mathrm{~m}^{-3}$ at st. f. There was a significant difference in the average of the mean hourly ${ }^{222} \mathrm{Rn}$ concentrations between the two stations [st. e: $54.3( \pm 20.1) \mathrm{Bq} \mathrm{m}^{-3}$; st. f: $34.2( \pm 10.4)$ $\mathrm{Bq} \mathrm{m} \mathrm{m}^{-3}$, Student's $t$-test, $p=0.0002$; Figure 4A]. The mean hourly SGD varied between 25.3 and $159.3 \mathrm{~cm}^{-1} \mathrm{day}^{-1}$ at st. e and between 1.9 and $32.8 \mathrm{~cm} \mathrm{day}^{-1}$ at st. $\mathrm{f}$. There was a significant difference in the average of the mean hourly SGD between the two stations (st. e: $99.8 \mathrm{~cm} \mathrm{day}^{-1}$; st. f: $4.9 \mathrm{~cm}^{\text {day }}{ }^{-1}$, Student's $t$-test, $p<0.0001$; Figure 4B). Average $( \pm \mathrm{SD})$ of the mean hourly water temperature was $18.3^{\circ} \mathrm{C}\left( \pm 0.25^{\circ} \mathrm{C}\right)$ and $18.2^{\circ} \mathrm{C}$ $\left( \pm 0.23^{\circ} \mathrm{C}\right)$ and values for salinity was $32.1( \pm 0.22)$ and 33.0
$( \pm 0.00)$ at sts. e and $f$, respectively. The difference was significant for salinity (Student's $t$-test, $p<0.0001$; Figure 4C) but not for temperature $(p>0.05)$.

The hourly DIN concentration ranged between 0.61 and $1.05 \mu \mathrm{M}$ at st. e and between 0.45 and $0.63 \mu \mathrm{M}$ at st. $\mathrm{f}$ (Figure 4D). The hourly DIP concentration ranged between 0.14 and $0.26 \mu \mathrm{M}$ at st. e and between 0.09 and $0.20 \mu \mathrm{M}$ at st. $\mathrm{f}$ (Figure 4E). The means of both hourly DIN (st. e: $0.76 \mu \mathrm{M}$, st. f: $0.52 \mu \mathrm{M}$ ) and DIN (st. e: $0.20 \mu \mathrm{M}$, st. f: $0.16 \mu \mathrm{M}$ ) were significantly higher at st. e (Student's $t$-test, $p<0.0001$ for both DIN and DIP).

The hourly Chl-a concentration ranged between 1.01 and 2.82 $\mu \mathrm{g} \mathrm{L}^{-1}$ at st. e and between 1.07 and $1.72 \mu \mathrm{g} \mathrm{L}^{-1}$ at st. f. The average was slightly higher at st. e $\left(1.94 \mu \mathrm{g} \mathrm{L}^{-1}\right)$ than at st. $\mathrm{f}$ (1.72 $\left.\mu \mathrm{g} \mathrm{L}^{-1}\right)$, without significant difference between the two sites (Student's $t$-test, $p=0.058$; Figure 4F).

\section{Feeding and Growth of Juvenile Marbled Sole by Cage Experiment}

A total of $92.3 \%$ (12 of 13 fishes) and $72.7 \%$ (10 of 13 fishes) of juvenile marbled sole analyzed for their stomach contents at sts. e and $\mathrm{f}$, respectively, had prey items in their stomachs. The most dominant prey organisms were gammarids, accounting for $71.2 \%$ 


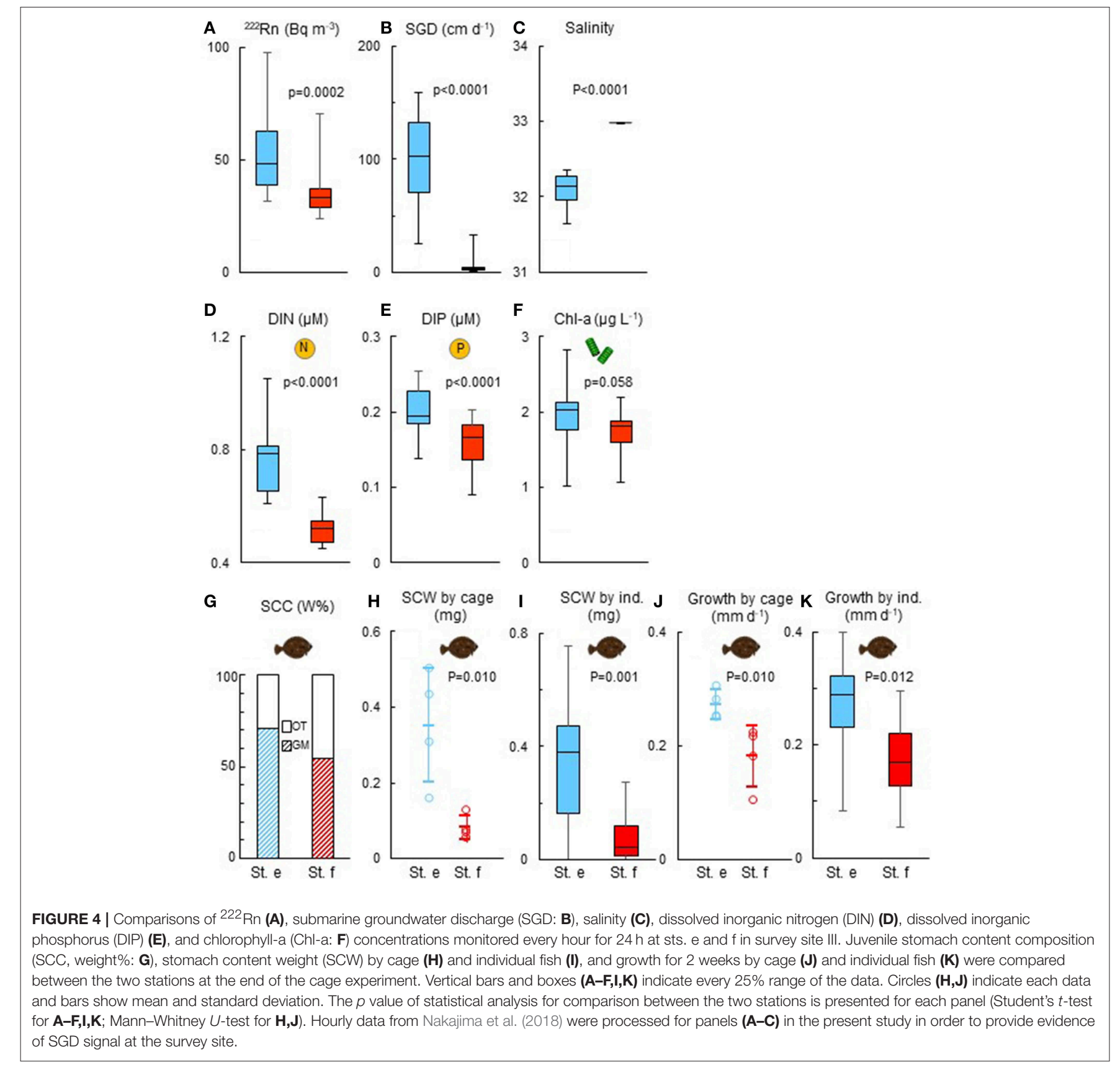

at st. e and $54.7 \%$ at st. f, followed by ostracods $(20.8 \%$ at st. e; $43.8 \%$ at st. f; Figure 4G). Other prey organisms accounted for 7.9 and $1.5 \%$ at sts. e and f, respectively.

Mean juvenile stomach content weight of each experimental group ranged between $0.16 \pm 0.15$ and $0.50 \pm 0.17 \mathrm{mg}$ at st. e and between $0.06 \pm 0.03$ and $0.13 \pm 0.13 \mathrm{mg}$ at st. $\mathrm{f}$ (Figure $4 \mathbf{H}$ ). There was a significant difference between the two stations (Mann-Whitney $U$-test, $p<0.05$ ). Mean of stomach content weight of individual juvenile at st. e $(0.36 \pm 0.09 \mathrm{mg})$ was also significantly higher than that at st. f $(0.09 \pm 0.02 \mathrm{mg}$; Figure 4I).

Mean juvenile growth rates by experimental group ranged between $0.25 \pm 0.10$ and $0.31 \pm 0.07 \mathrm{~mm} \mathrm{day}^{-1}$ at st. e and between $0.11 \pm 0.03$ and $0.22 \pm 0.07 \mathrm{~mm} \mathrm{day}{ }^{-1}$ at st. f (Figure 4J). The difference between the two stations was significant (Mann-Whitney $U$-test, $p<0.05$ ). Mean of individual juvenile growth rate at st. e $\left(0.27 \pm 0.09 \mathrm{~mm} \mathrm{day}^{-1}\right)$ was also significantly higher than that at st. e $\left(0.18 \pm 0.07 \mathrm{~mm} \mathrm{day}^{-1}\right.$ : student's $t$-test, $p=0.012$; Figure $4 \mathbf{K})$.

Mean stable carbon isotope ratio of the juvenile marbled sole sampled at the end of the experiment from the cages at sts. e $(-18.26 \pm 0.19 \%)$ and $\mathrm{f}(-18.11 \pm 0.17 \%$ o $)$ was intermediate between values of the juveniles sampled from the stock tank at the start of the cage experiment $(-18.9 \pm 0.46 \%$ o $)$ and wild marbled sole juveniles collected at sts. e $(-16.64 \pm 0.32 \%$ ) and $\mathrm{f}(-16.00 \pm 0.43 \%$; Figure 5$)$. The stable carbon isotope ratio of the juveniles in the stock tank was slightly higher than the values 


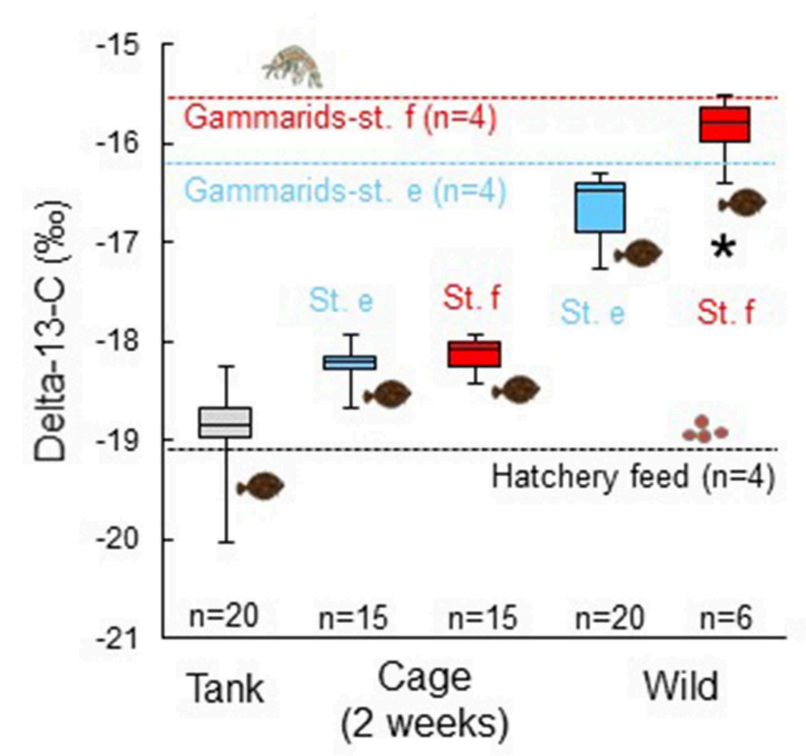

FIGURE 5 | Stable carbon isotope ratio of muscle of juvenile marbled sole sampled from the rearing tank before the experiment (Tank), after the cage experiment for 2 weeks (Cage), and wild marbled sole collected at sts. e and $f$ (Wild). Vertical bars and boxes indicate every $25 \%$ range of the data. Mean values for gammarids as major prey organisms for the juvenile marbled sole at sts. $e$ and $f$ and hatchery feed for the juveniles are shown as broken lines. Asterisk shows a significant difference in the isotope ratio of wild fishes between sts. e and $f(p=0.0006)$.

of the hatchery feed $(-19.08 \pm 0.17 \%$ ) and the values of wild juveniles were slightly lower than those of gammarids collected at each station, with the most dominant prey item both in the juvenile stomachs and water (e: $-16.16 \pm 1.80 \%$; f: $-15.66 \pm$ $1.31 \%$ ). The stable carbon isotope ratio of the juvenile marbled flounder sampled from the cages was not significantly different between sts. e and $\mathrm{f}$ (Mann-Whitney $U$-test, $p=0.504)$. The values of both wild juvenile marbled sole and gammarids at st. e were lower than those at st. f. There was a significant difference in the stable carbon isotope ratio of the wild juveniles between the two stations ( $U$-test, $p=0.0006)$.

\section{DISCUSSION}

In the present study, first direct evidence that fish feeding and growth were elevated by submarine groundwater was obtained by an on-site experiment and quantitative samplings. The experiment using cages moored on the sea bottom confirmed that the fishes obtained nutrition at a fixed place in nature. The quantitative sampling at three sites with different hydrodynamic properties showed that correspondence of high SGD with high biological production from producer to secondary consumers prevails in coastal marine areas. These findings demonstrate a missing trophic linkage in the coastal boundary area that originates from nutrients of terrestrial origin provided via submarine groundwater and promotes marine fish production.

\section{Validity of Cage Experiment}

The mean growth rate of juvenile marbled sole at the area with higher SGD (st. e: $0.22 \pm 0.09 \mathrm{~mm} \mathrm{day}{ }^{-1}$ at $18.3 \pm$ $0.25^{\circ} \mathrm{C}$ ) approximates those of juveniles cultured under the same temperatures $\left(0.25 \mathrm{~mm}^{-1 a y}{ }^{-1}\right.$ at $17.8^{\circ} \mathrm{C}$ : Mutsutani, 1988 ; $0.11-$ $0.96 \mathrm{~mm} \mathrm{day}^{-1}$ at $8-26^{\circ} \mathrm{C}$ : Kusakabe et al., 2017), although the juvenile growth rate varies, being highly affected by ambient temperatures. It is plausible that the condition for feeding during the experiment at st. e was maintained at a level generally appropriate for their growth. The period of the experiment ( 2 weeks) is considered long enough to evaluate the effect of difference in environmental conditions for feeding on their growth because of the half-life period of carbon and nitrogen stable isotopic ratios in the juvenile muscles (about 2 weeks: Hamaoka et al., 2016). These results indicate that the difference observed in the feeding and growth of juvenile marbled sole between the experimental stations reflects the environmental properties that were affected by the presence/absence of effects of SGD in surrounding water.

\section{Effects of Submarine Groundwater Discharge on Primary Production and Primary Consumer}

Nutrients supplied via SGD increase microalgal and macrophyte biomass and production in marine ecosystems of the world (Lecher et al., 2015, 2017; Lecher and Mackey, 2018). In tropical systems, nitrogen-enriched groundwater enhances primary production of benthic ecosystems (Fourqurean et al., 1992; Peterson and Heck, 2001; Fourqurean and Zieman, 2002; Carruthers et al., 2005; Bowen et al., 2007; de Sieyes et al., 2008). In the present study, nutrients supplied via submarine groundwateris potentially important for primary production in the coastal sea areas because there are no rivers nearby the three survey sites. The higher primary production rate of benthic microalgae in the areas with high SGD commonly observed at all three sites with different hydrographic features in the present study shows that nutrients provided via SGD contributed to primary production in the benthic ecosystems in these sites. In the pelagic ecosystem, on the other hand, the effect of SGD on phytoplankton production has been reported to differ between types of SGD (Sugimoto et al., 2017). An in situ experiment to elucidate the response of phytoplankton primary productivity to SGD clarified that the mechanism by which SGD affects phytoplankton production differs from one ecosystem to another because of variable hydro-geographical properties, such as the type of groundwater discharge (i.e., spring type or seepage type: Sugimoto et al., 2017). At a site in Obama Bay, central Japan, which is characterized by seepage-type SGD, a significant positive relationship between in situ phytoplankton primary productivity and ${ }^{222} \mathrm{Rn}$ concentration was observed probably due to nutrient-limited water column conditions. On the other hand, at volcanic coastal sites in northern and southern Japan, which are dominated by spring-type SGD, no clear relationships between in situ phytoplankton primary productivity and ${ }^{222} \mathrm{Rn}$ concentration were found, suggesting that submarine springs have negative impacts on phytoplankton growth rates around 


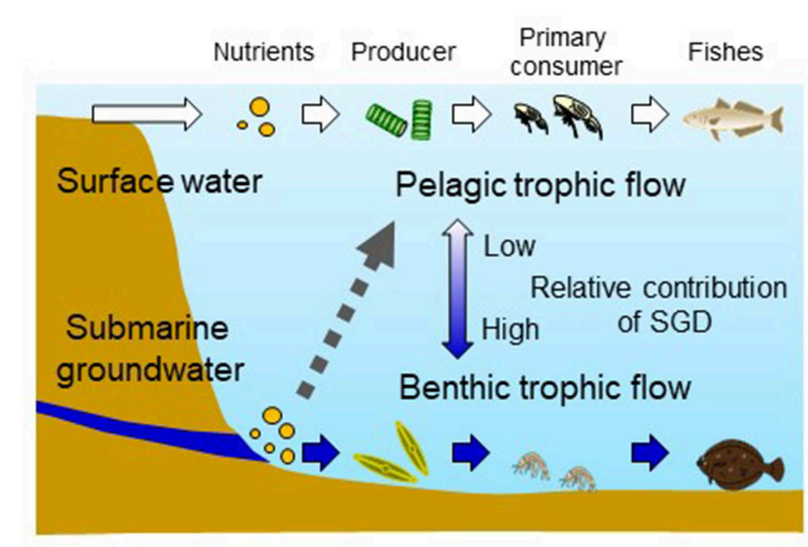

FIGURE 6 | A schematic drawing of contribution of nutrients provided by surface (river) water and SGD to pelagic and benthic trophic flows of coastal waters. Contribution of nutrients of SGD origin to the pelagic trophic flow has been still unknown or underestimated due to mixing of water and nutrients (indicated by an arrow with a broken line). Relative contributions of surface water and submarine groundwater are considered to be higher to the production of high-order ecosystem organisms of pelagic and benthic trophic flow, respectively. The contribution of nutrients of SGD origin to both pelagic and benthic trophic flows is assumed to be higher in an area where the influx of surface water is minimal and water mixing by tide prevails such as in the survey site III (Seto Inland Sea) in the present study.

vent sites, possibly due to gradient in environmental conditions such as temperature and salinity (Sugimoto et al., 2017).

In addition to the SGD type, tidal current would affect pelagic primary production through mixing water. The maximum DTA during spring tide period around site III located in the Seto Inland Sea exceeds $4 \mathrm{~m}$. The chlorophyll-a concentration as an index of phytoplankton production was not significantly different between the two stations (sts. e and f) while difference in the benthic microalgae production was significant. In contrast, the effect of SGD on primary production would be more visible in the near-bottom layer of the water column regardless of physical properties and SGD types in each area. Consequently, the contribution of nutrition provided via SGD to the benthic food web is expected to be higher in coastal marine waters with high tidal mixing and less freshwater input through rivers flowing into the surrounding area as site III in the present study (Figure 6). Further studies applying the experimental protocols developed in the present study will enable elucidation of how SGD contributes to the pelagic and benthic food web depending on different tidal periods, geographical shapes of coastal area, and SGD type.

Groundwater discharge has been shown to have impacts on benthic microalgae and macrofauna in other coastal areas (Miller and Ullman, 2004; Waska and Kim, 2010). In the present study, the abundance of gammarids, the main prey organisms of juvenile marbled sole, was 2.4 (site I) to 15.2 (site III) times higher in the vicinity of the SGD (Figure 3). These gammarids include herbivores that feed on phytoplankton and benthic microalgae (Hata et al., 2016), showing the influence of SGD-originated nutrients on the primary consumer through elevation of the benthic primary production. Further, the gammarids seem to play an important role in connecting benthic primary production with high-order trophic level predators in the vicinity of SGD in the present study sites (Figure 6).

\section{Influence on Fish Production}

The present study is the first case to evaluate the influence of SGD on fish growth and feeding in marine coastal waters. The SGD has been believed to highly contribute to the coastal fisheries production at many locations of the world (Moosdorf and Oehler, 2017). To date, elevation of fish abundance and biomass has been observed in the vicinity of SGD (Hata et al., 2016; Shoji et al., 2017; Utsunomiya et al., 2017). However, whether the fishes grow utilizing the nutrients originated from SGD remains unknown. In the present study, the carbon stable isotope analysis supports the conclusion that nutrients of terrestrial origin provided via SGD were utilized by juvenile marbled sole. The stable carbon isotope ratio at the end of the field experiment was intermediate between juveniles sampled from the stock tank and wild juveniles, indicating that these juveniles in the cages were acclimating to prey organisms in nature during the 2-week experiment, which approximates the time length of half-life of the isotope ratio of this species (Hamaoka et al., 2016). The lower values of stable carbon isotope ratio of gammarids at st. e than at st. $\mathrm{f}$ would prove the higher influence of nutrients provided via SGD on marbled sole juveniles through benthic food web (Hata et al., 2016) prevailing at st. e than at st. f.

\section{DATA AVAILABILITY}

The raw data supporting the conclusions of this manuscript will be made available by the authors, without undue reservation, to any qualified researcher.

\section{ETHICS STATEMENT}

All applicable institutional and/or national guidelines for the care and use of animals were followed. The procedures and protocols followed the guidelines of the Committee for Animal Experiment of Hiroshima University (CD001651) and those for the use of fishes in research by the Ichthyological Society of Japan (http://www.fish-isj.jp/english/guidelines.html). No ethic or law violations are included in the present study.

\section{AUTHOR CONTRIBUTIONS}

KF, JS, RS, and MakT designed the study. KF, JS, RS, TN, HH, MasT, and OT performed the field survey. KF, JS, RS, TN, and $\mathrm{HH}$ analyzed data. JS and RS drafted the manuscript.

\section{FUNDING}

This study was partially supported by Grants-in-Aid for Scientific Research (B) (16H04971 and 17H04624 to JS) and by the Ministry of Agriculture, Forestry and Fisheries of Japan. 


\section{ACKNOWLEDGMENTS}

The authors would like to thank Mr. Sadaharu Iwasaki, Yuji Terada, Shohei Takemoto, Kentaro Note, Kentaro

\section{REFERENCES}

Bowen, J. L., Kroeger, K. D., Tomasky, G., Pabich, W. J., Cole, M. L., Carmichael, R. H., et al. (2007). A review of land-sea coupling by groundwater discharge of nitrogen to New England estuaries: mechanisms and effects. Appl. Geochem. 22, 175-191. doi: 10.1016/j.apgeochem.2006.09.002

Burnett, W. C., Kim, G., and Lane-Smith, D. (2001). A continuous monitor for assessment of 222Rn in the coastal ocean. J. Radioanal. Nucl. Chem. 249, 167-172. doi: 10.1023/A:1013217821419

Carruthers, T. J. B., van Tussenbroek, B. I., and Dennison, W. C. (2005). Influence of submarine springs and wastewater on nutrient dynamics of Caribbean seagrass meadows. Est. Coast. Shelf Sci. 64, 191-199. doi: 10.1016/j.ecss.2005.01.015

Charette, M. A., Moore, W. S., and Burnett, W. C. (2008). "Uranium- and thorium-series nuclides as tracers of submarine groundwater discharge," in $U_{-}$ Th Series Nuclides in Aquatic Systems, eds S. Krishnaswami and J. Kirk-Cochran (Amsterdam: Elsevier), 155-91.

Church, T. M. (1996). An underground route for the water cycle. Nature 380, 579-580. doi: 10.1038/380579a0

de Sieyes, N., Yamahara, K., Layton, B., Joyce, E., and Boehm, A. (2008). Submarine discharge of nutrient-enriched fresh groundwater at Stinson Beach, California is enhanced during neap tides. Limnol. Oceanogr. 53, 1434-1445. doi: 10.4319/lo.2008.53.4.1434

Dimova, N., Burnett, W. C., and Lane-Smith, D. (2009). Improved automated analysis of radon $(222 \mathrm{Rn})$ and thoron $(220 \mathrm{Rn})$ in natural waters. Environ. Sci. Technol. 43, 8599-8603. doi: 10.1021/es902045c

Field, C. B., Behrenfeld, M. J., Randerson, J. T., and Falkowski, P. (1998). Primary production of the biosphere: integrating terrestrial and oceanic components. Science 281, 237-240. doi: 10.1126/science.281.5374.237

Fourqurean, J. W., and Zieman, J. C. (2002). Nutrient content of the seagrass Thalassia testudinum reveals regional patterns of relative availability of nitrogen and phosphorus in the Florida Keys USA. Biogeochemistry 61, 229-245. doi: 10.1023/A:1020293503405

Fourqurean, J. W., Zieman, J. C., and Powell, G. V. N. (1992). Phosphorus limitation of primary production in Florida Bay: evidence from C:N:P ratios of the dominant seagrass, Thalassia testudinum. Limnol. Oceanogr. 37, 162-171. doi: 10.4319/lo.1992.37.1.0162

Fujita, K., Tomiyama, T., and Shoji, J. (2017). "Does submarine groundwater discharge affect growth of juvenile flatfish? A cage experiment in the Seto Inland Sea, Japan," in Abstract retrieved from Abstract book of the International Flatfish Symposium-2017 (Saint-Malo).

Hamaoka, H., Shoji, J., and Hori, M. (2016). Turnover rates of carbon and nitrogen stable isotopes in juvenile marbled flounder Pleuronectes yokohamae estimated by diet switch. Ichthyol. Res. 63, 201-206. doi: 10.1007/s10228-015-0488-1

Hata, M., Sugimoto, R., Hori, M., Tomiyama, T., and Shoji, J. (2016). Occurrence, distribution and prey items of juvenile marbled sole Pseudopleuronectes yokohamae around a submarine groundwater seepage on a tidal flat in southwestern Japan. J Sea Res. 111, 47-53. doi: 10.1016/j.seares.2016.01.009

Holmes, R. M., Aminot, A., Kerouel, R., Hooker, B. A., and Peterson, B. J. (1999). A simple and precise method for measuring ammonium in marine and freshwater ecosystems. Can. J. Fish. Aquat. Sci. 56, 1801-1808. doi: 10.1139/f99-128

Honda, H., Taniguchi, M., Ono, M., Hosono, T., Umezawa, Y., Sugimoto, R., et al. (2015). "Relationship between radon-222 concentrations in coastal water and environmental conditions in Japan," Abstract retrieved from Abstract book of the 10th International Conference on the Methods and Applications of Radioanalytical Chemistry MARC X (Kailua-Kona, HI).

Hosono, T., Ono, M., Burnett, W. C., Tokunaga, T., Taniguchi, M., and Akimichi, T. (2012). Spatial distribution of submarine groundwater discharge and associated nutrients within a local coastal area. Environ. Sci. Technol. 46, 5319-5326. doi: 10.1021/es2043867
Yoshikawa, and other members of the Takehara Marine Laboratory, Hiroshima University, for their assistance in the field experiment and two reviewers for their valuable comments on the manuscript.

Kamimura, Y., and Shoji, J. (2013). Does macroalgal vegetation cover influence post-settlement survival and recruitment potential of juvenile black rockfish Sebastes cheni? Estuar. Coast. Shelf Sci. 129, 86-93. doi: 10.1016/j.ecss.2013.05.028

Kim, G., Ryu, J. W., Yang, H. S., and Yun, S. T. (2005). Submarine groundwater discharge (SGD) into the Yellow Sea revealed by 228Ra and 226Ra isotopes: implications for global silicate fluxes. Earth Planet. Sci. Lett. 237, 156-166. doi: 10.1016/j.epsl.2005.06.011

Kobayashi, S., Ikuta, K., Sugimoto, R., Honda, H., Yamada, M., Tominaga, O., et al. (2019). Estimation of submarine groundwater discharge and its impact on nutrient environment in Kamaiso beach, Yamagata, Japan. Bull. Jap. Soc. Fish. Sci. 85, 30-39. doi: 10.2331/suisan.18-00020

Kobayashi, S., Sugimoto, R., Honda, H., Miyata, Y., Tahara, D., Tominaga, O., et al. (2017). High-resolution mapping and time-series measurements of $222 \mathrm{Rn}$ concentrations and biogeochemical properties related to submarine groundwater discharge along the coast of Obama Bay, a semi-enclosed sea in Japan. Prog. Earth Planet. Sci. 4:6. doi: 10.1186/s40645-017-0124-y

Kusakabe, K., Hata, M., Shoji, J., Hori, M., and Tomiyama, T. (2017). Effects of water temperature on feeding and growth of juvenile marbled flounder Pseudopleuronectes yokohamae under laboratory conditions: evaluation by group- and individual-based methods. Fisheries Sci. 83, 215-219. doi: 10.1007/s12562-016-1053-1

Lecher, A. L., Mackey, K., Kudela, R., Ryan, J., Fisher, A., Murray, J., et al. (2015). Nutrient loading through submarine groundwater discharge and phytoplankton growth in Monterey bay, CA. Environ. Sci. Technol. 49, 6665-6673. doi: 10.1021/acs.est.5b00909

Lecher, A. L., and Mackey, K. R. M. (2018). Synthesizing the effects of submarine groundwater discharge on marine biota. Hydrology 5:60. doi: 10.3390/hydrology5040060

Lecher, A. L., Mackey, K. R. M., and Paytan, A. (2017). River and submarine groundwater discharge effects on diatom phytoplankton abundance in the Gulf of Alaska. Hydrology 4:61. doi: 10.3390/hydrology4040061

Miller, D. C., and Ullman, W. J. (2004). Ecological consequences of ground water discharge to Delaware Bay, United States. Ground Water 42, 959-970. doi: 10.1111/j.1745-6584.2004.tb02635.x

Moosdorf, N., and Oehler, T. (2017). Societal use of fresh submarine groundwater discharge: an overlooked water resource. Earth Sci. Rev. 171, 338-348. doi: 10.1016/j.earscirev.2017.06.006

Mutsutani, K. (1988). Growth and metamorphosis of the marbled sole larvae limanda yohohamae (GÜNTER) in culture. Aquacul. Sci. 36, 27-32.

Nagata, T., and Miyajima, T. (2008). Stable Isotopes in Environmental Assessment of Watersheds-Progress Towards an Integrated Approach. Kyoto: Kyoto University Press.

Nakajima, T., Sugimoto, R., Tominaga, O., Takeuchi, M., Honda, H., Shoji, J., et al. (2018). Fresh and recirculated submarine groundwater discharge evaluated by geochemical tracers and a seepage meter at two sites in the Seto Inland Sea, Japan. Hydrology 5:61. doi: 10.3390/hydrology5040061

Peterson, B. J., and Heck, K. L. Jr. (2001). Positive interactions between suspensionfeeding bivalves and seagrass: Aa facultative mutualism. Mar. Ecol. Prog. Ser. 213, 143-155. doi: 10.3354/meps213143

Peterson, B. J., Stubler, A. D., Wall, C. C., and Gobler, C. J. (2012). Nitrogen-rich groundwater intrusion affects productivity, but not herbivory, of the tropical seagrass Thalassia testudinum. Aquat. Biol. 15, 1-9. doi: 10.3354/ab00413

Rodellas, V., Garcia-Orellanaa, J., Masquéa, P., Feldmane, M., and Weinsteine, Y. (2015). Submarine groundwater discharge as a major source of nutrients to the Mediterranean Sea. Proc. Natl. Acad. Sci. U.S.A. 112, 3926-3930. doi: $10.1073 /$ pnas.1419049112

Sanders, T. G. Jr., Biddanda, B. A., Stricker, C. A., and Nold, S. C. (2011) Benthic macroinvertebrate and fish communities in Lake Huron are linked to submerged groundwater vents. Aquat. Biol. 21, 1-11. doi: 10.3354/ab00318 
Santos, I. R., Peterson, R. N., Eyre, B. D., and Burnett, W. C. (2010). Significant lateral inputs of fresh groundwater into a stratified tropical estuary: evidence from radon and radium isotopes. Mar. Chem. 121, 37-48. doi: 10.1016/j.marchem.2010.03.003

Shoji, J., Sugimoto, R., and Tominaga, O. (2017). Land-Ocean Interactions Through Groundwater/Submarine Groundwater and Human Society. Tokyo: Koseishakoseikaku.

Sirois, P., and Dodson, J. J. (2000). Influence of turbidity, food density and parasites on the ingestion and growth of larval rainbow smelt Osmerus mordax in an estuarine turbidity maximum. Mar. Ecol. Prog. Seri. 193, 167-179. doi: $10.3354 /$ meps 193167

Slomp, C. P., and van Cappellen, P. (2004). Nutrient inputs to the coastal ocean through submarine groundwater discharge: controls and potential impact. J. Hydrol. 295, 64-86. doi: 10.1016/j.jhydrol.2004.02.018

Stieglitz, T. C., van Beek, P., Souhaut, M., and Cook, P. G. (2013). Karstic groundwater discharge and seawater recirculation through sediments in shallow coastal Mediterranean lagoons, determined from water, salt and radon budgets. Mar. Chem. 156, 73-84. doi: 10.1016/j.marchem.2013.05.005

Sugimoto, R., Honda, H., Kobayashi, S., Takao, Y., Tahara, D., Tominaga, O., et al. (2016). Seasonal changes in submarine groundwater discharge and associated nutrient transport into a tideless semi-enclosed embayment (Obama Bay, Japan). Estuar. Coast. 39, 13-26. doi: 10.1007/s12237-0159986-7

Sugimoto, R., Kitagawa, K., Nishi, S., Honda, H., Yamada, M., Kobayashi, S., et al. (2017). Phytoplankton primary productivity around submarine groundwater discharge in nearshore coasts. Mar. Ecol. Prog. Seri. 563, 25-33. doi: 10.3354/meps11980

Swarzenski, P. W., Reich, C., Kroeger, K. D., and Baskaran, M. (2007). Ra and $\mathrm{Rn}$ isotopes as natural tracers of submarine groundwater discharge in Tampa Bay, Florida. Mar. Chem. 104, 69-84. doi: 10.1016/j.marchem.2006. 08.001

Taniguchi, M., Burnett, W. C., Cable, J. E., and Turner, J. V. (2002). Investigation of submarine groundwater discharge. Hydrol. Process 16, 2115-2129. doi: 10.1002/hyp.1145
Taniguchi, M., and Iwakawa, H. (2001). Measurements of submarine groundwater discharge rates by a continuous heat-type automated seepage meter in Osaka Bay, Japan. J. Groundwater Hydrol. 43, 271-277. doi: 10.5917/jagh1987.43.271

Tomas, F., Abbott, J. M., Steinberg, C., Balk, M., Williams, S. L., and Stachowicz, J. J. (2011). Plant genotype and nitrogen loading influence seagrass productivity, biochemistry, and plant-herbivore interactions. Ecology 92, 1807-1817. doi: 10.1890/10-2095.1

Utsunomiya, T., Hata, M., Sugimoto, R., Honda, H., Kobayashi, S., Miyata, Y., et al. (2017). Higher species richness and abundance of fish and benthic invertebrates around submarine groundwater discharge in Obama Bay, Japan. J. Hydrol. 11, 139-146. doi: 10.1016/j.ejrh.2015.11.012

Valiela, I., Costa, J., Foreman, K., Teal, J. M., Howes, B., and Aubrey, D. (1990). Transport of groundwater-borne nutrients from watersheds and their effects on coastal waters. Biogeochemistry 10, 177-197. doi: 10.1007/BF00003143

Wada, T., Aritaki, M., Yamashita, Y., and Tanaka, M. (2007). Comparison of low-salinity adaptability and morphological development during the early life history of five pleuronectid flatfishes, and implications for migration and recruitment to their nurseries. J. Sea Res. 58, 241-254. doi: 10.1016/j.seares.2007.03.004

Waska, H., and Kim, G. (2010). Differences in microphytobenthos and macrofaunal abundances associated with groundwater discharge in the intertidal zone. Mar. Ecol. Prog. Ser. 407, 159-172. doi: 10.3354/meps08568

Conflict of Interest Statement: The authors declare that the research was conducted in the absence of any commercial or financial relationships that could be construed as a potential conflict of interest.

Copyright (c) 2019 Fujita, Shoji, Sugimoto, Nakajima, Honda, Takeuchi, Tominaga and Taniguchi. This is an open-access article distributed under the terms of the Creative Commons Attribution License (CC BY). The use, distribution or reproduction in other forums is permitted, provided the original author(s) and the copyright owner(s) are credited and that the original publication in this journal is cited, in accordance with accepted academic practice. No use, distribution or reproduction is permitted which does not comply with these terms. 